T. В. Саварин

ДВНЗ “Тернопільський державний медичний університет імені І. Я. Горбачевського МОЗ Украӥни”

\title{
ОРГАНІЗАЦІЯ МЕДИЧНОЇ ОСВІТИ НА ЗАХІДНОУКРАЇНСЬКИХ ЗЕМЛЯХ У ДРУГІЙ ПОЛОВИНІ ХVIII - XIX СТ.
}

T. V. Savaryn

\author{
I. Horbachevsky Ternopil State Medical University \\ THE ORGANIZATION OF MEDICAL EDUCATION IN WESTERN \\ UKRAINE IN THE SECOND HALF OF XVIII - XIX CENTURY
}

\begin{abstract}
Мета роботи - проаналізувати історію виникнення та організації навчальних закладів для підготовки медичних працівників на західноукраїнських землях у другій половині XVIII - XIX ст.

Основна частина. У статті використаний бібліографічний метод вивчення бібліотечних каталогів; класифікація та систематизація джерел з історії медицини, педагогіки; хронологічний метод, що дозволив проаналізувати особливості становлення і розвитку медичної освіти у різні історичні періоди.

У статті відтворено структуру системи медичної освіти на західноукраїнських землях у другій половині XVIII - XIX ст.; уточнено відомості про професійну та наукову діяльність видатних українських лікарів цього періоду.

Висновок. Визначальними критеріями процесу розвитку медичної освіти можна назвати: поступове зростання мережі закладів медичної освіти, збільшення числа кафедр, збільшення кількості студентів і викладачів у них, розширення змісту навчання, зміна рівня професійної підготовки медиків.
\end{abstract}

Ключові слова: медична освіта; західноукраїнські землі; медики; навчання; дослідження.

The aim of the work - to analyze the history of development and organization of medical educational establishments in Western Ukraine in the second half of XVIII - XIX century.

The main body. The article discusses the method of analyzing bibliographic catalogues, the classification and systematization of primary sources in History of Medicine and Pedagogy, and the chronological method that identifies the establishment and development of medical education during different historical periods.

The paper describes the structure of medical education system in Western Ukraine in the second half of XVIII - XIX century and summarizes the existing data about professional and scientific activity of Ukrainian doctors of this period.

Conclusion. The main characteristics of development of medical education of this historic period are the gradual increase in medical establishments, medical departments, medical faculty and students; the improvement and transformation of medical personnel education and training.

Key words: medical education; Western Ukraine; medical personnel; education; research.

Вступ. Медичну освіту не можна розглядати відокремлено від загальної системи професійної освіти, особливостей її розвитку на сучасному етапі. Водночас необхідно враховувати традиції, що склалися в системі охорони здоров’я населення в цілому, та власне специфіку самої медичної освіти. При цьому сучасне формування медичної освіти потребує вивчення історичного досвіду їі здійснення в різних регіонах України, зокрема й у XIX - на початку XX ст.

Історією становлення медичної освіти в Україні здавна цікавилось багато вчених, зокрема: Т. Бу-

(C) Т. В. Саварин рачинський, С. Верхратський, Л. Гонсьоровський, Б. Криштопа, Я. Лукашевич, М. Музика, В. Шумовський, І. Огієнко, Є. Озаркевич, М. Панчишин, О. Рузанова, С. Стажинський, І. Шапіро, М. Шегедин, Л. Фінкель. Вивчали цю широку проблему і сучасні дослідники: А. Вихрущ, Л. Клос, В. Кравець, В. Сагарда, Б. Ступарик, М. Кушик.

Мета роботи - проаналізувати історію виникнення та організації навчальних закладів для підготовки медичних працівників на західноукраїнських землях у другій половині XVIII - XIX ст.

Основна частина. У другій половині XVIII ст., за свідченням багатьох дослідників, медичне обслу- 
говування населення західноукраїнських територій було незадовільним. За часів Австро-Угорщини (1771-1918) ні в Галичині, ні в Закарпатті не було збудовано жодної лікарні у селі. Лікарні будували лише в повітових містах, і то не в усіх: з 46 повітових міст лікарні були тільки в 27. Стаціонарна медична допомога була платна, недоступна для більшості селян, і тому значна кількість ліжок у лікарнях не використовувалась [2-4].

Отож, державної санітарної служби і закладів медичної освіти практично не існувало. За свідченням дослідників історії медицини, австрійська реформа охорони здоров’я (1770) торкнулася і західноукраїнських регіонів. Імператриця Австрії Марія Терезія з метою поліпшення медичної опіки над населенням, розвитку медичної освіти і науки у королівстві Галичина та Лодомирія декретом від 22 грудня 1772 р. призначила доктора медицини Андрея Крупинського крайовим протомедиком Галичини. Йому було доручено створити на західноукраїнських землях систему медичної служби і медичної освіти.

Урочисте відкриття Львівського акушерського колегіуму відбулося 1 жовтня 1773 р. Цей день ознаменував зародження середньої медичної освіти на західноукраїнських землях. Навчання в колегіумі було безкоштовним. Більше того, слухачі перебували на повному утриманні землевласників, які скерували їх на навчання. 3 губернаторського фонду вони одержували по одному гульдену на тиждень. Слухачами колегіуму могли стати фізично здорові, морально стійкі особи обох статей віком від 21 до 30 років. Звичайно, підбирали інтелектуально розвинених, які відзначалися милосердям та любов’ю до акушерської справи.

За статутом, навчання в колегіумі тривало від 1-го до 3-х років. При колегіумі діяли курси прискореної підготовки акушерок. Це сприяло значному поліпшенню акушерської допомоги в королівстві [2].

При такій системі освіти відчувалась гостра нестача середнього медичного персоналу. Незважаючи на це, багато з них не мало роботи або займалось приватною практикою. На цей час дрібні лікувальні установи взагалі працювали без середнього медичного персоналу, а у великих - на одного лікаря припадав лише один середній медичний працівник. У зв’язку з цим їхні умови праці були вкрай важкими, а платня мізерною. В клініках єдиного в Західній Україні медичного факультету Львівського університету медичними сестрами працювали переважно монашки, які недостатньо володіли навіть найелементарнішими навичками догляду за хворими [2].

Важливою у розвитку медичної освіти на західноукраїнських землях була організація Львівської медико-хірургічної школи в 1784 р., де готували акушерок, аптекарів, хірургів. Термін навчання становив два роки, з 1833 р. термін навчання був трирічним, у 1874-1875 н. р. школу було закрито. В 1875 р. у Львові було організовано імператорську школу для підготовки акушерок. Із терміном навчання від 2-х до 7 місяців було створено в 1895 р. школу для медичних сестер на базі лікарні. Термін навчання в акушерських школах становив від трьох і п’яти місяців на Закарпатті, до 8 міс. на Буковині, протягом яких учнів навчали практичних навичок [7, 9, 13].

На час переходу Львова і галицьких земель у 1773 р. під владу Австрії у місті було 25 тис. жителів, з них лікарів лише 6 (2 французи, 1 італієць, 1 чех, 2 поляки). На території Західної України (1772-1918) медичну допомогу населенню, крім лікарів та представників народної медицини, надавали цирулики, хірурги, акушерки, повитухи, фельдшери, сестри милосердя та медичні сестри, тобто медпрацівники середньої ланки. Підготовка відповідних фахівців здійснювалась різними шляхами: від індивідуального учнівства для цируликів, повитух чи сестер милосердя (шариток) до навчання у державних і приватних школах, що готували хірургів, акушерок, фельдшерів та медсестер. Організація навчального процесу в спеціалізованих медичних школах у різних частинах регіону помітно відрізнялася. Австрійський уряд встановив державні посади окружних та повітових лікарів. Вони мали контролювати діяльність осіб, які займались медичною практикою, дбати про санітарно-гігієнічний порядок, забезпечення населення чистою питною водою, проведення протиепідемічних заходів. Їм дозволялось також займатись лікувальною роботою шляхом приватної практики [4].

На початку XX ст. у Західному регіоні українських земель позначилися три основні напрямки у розвитку фахової медичної освіти середнього рівня. Так, у Галичині функціонували навчальні заклади з підготовки акушерок і хірургів, а також школа медичних сестер; на Закарпатті та на Буковині готували виключно акушерок, а на Волині фельдшерів та акушерок [8].

Окремі дослідники відзначили той факт, що рівень підготовки хірургів та акушерок у Галичині був значно вищим порівняно з іншими частинами 
регіону, оскільки навчальний курс уже у XIX ст. включав три основні групи дисциплін: загальноосвітні, фахово орієнтовані та спеціальні. На Волині такого рівня було досягнуто лише на початку ХХ ст., після освітньої реформи 1903 р. в Росії. На Закарпатті та на Буковині підготовка акушерок мала практичний характер. Спільною рисою для всіх закладів було те, що обов'язковим компонентом освіти була практична підготовка. Слід зазначити, що у перерахованих вище закладах викладання здійснювалося: на Буковині - румунською, на Закарпатті - угорською або німецькою, в Галичині польською, на Волині - російською мовами. Природно, що навчання здійснювалося за іншомовними підручниками (тобто не українськими). При цьому викладачами медичних навчальних закладів здебільшого призначалися повітові лікарі та керівники шпиталів, за місцем базування шкіл [8].

Дослідниця Л. Є. Клос зазначає, що фахівців-лікувальників того часу можна розділити за рівнем освіченості на три групи: перша група - випускники університетів і академій, друга - хірурги 3 університетською освітою, третя - “цирулики” (цирульники). Останні належали до професійних об'єднань - цехів, які одночасно були школами практичного навчання. Саме цирульники виконували функції асистентів під час проведення операцій професорами в університетських клініках. Поряд із згаданими категоріями медиків населенню середньовічної Європи також надавали допомогу представники народної медицини (знахарі, костоправи, кровопускателі) [7].

Отже, ні в Галичині, ні в Закарпатті протягом майже всього XIX ст. не було вищої медичної школи. Лише в 1894 р. у Львові відкрито при університеті медичний факультет, вступ до якого українцям було обмежено (за клопотанням єзуїтів у 1661 р. у Львові було відкрито університет з медичним факультетом, але на вимогу Краківського університету (через побоювання конкуренції) його через 2 роки закрито; вдруге медичний факультет було відкрито в 1784 р. і знову закрито в 1805 р.). Діяльність медичних факультетів університетів, які були на території України, визначалась у межах освітньої політики імперій. За 25 років існування за часів Австро-Угорщини цього факультету було випущено 544 лікарів, серед них лише 40 українців. За часів буржуазної Польщі вступ українців на медичний факультет Львівського університету допускався в межах 5 \%. Українці, як правило, могли працювати лише як приватні лікарі. Не маючи змоги працювати на штатних посадах у клініках, лікарнях, вони не могли досягти високої кваліфікації, а до науково-педагогічної діяльності українців зовсім не допускали [2, 3].

Дослідниця цього періоду Л. Є. Клос виділяє два періоди у діяльності цього закладу: 1784-1805 рр. та 1894-1918 рр., між якими виявлено суттєві відмінності у змісті освіти, формах і методах навчання. Так, упродовж першого періоду факультет готував лікарів за австрійською програмою, традиційною для середньовічних університетів. Курс навчання тривав сім років, із яких три перші - це студії на обов'язковому філософському факультеті, а наступні чотири роки присвячувалися вивченню фахово орієнтованих дисциплін (анатомії, фізіології, фармакогнозії, патології, природознавства для медиків) та спеціальних предметів (хірургії, акушерства, клініки та спецкурсу з окулістики). Кількість студентів на медичному факультеті (у той час непрестижному) була невеликою, що й спричинило скорочення змісту освіти, а згодом і закриття факультету.

У наступному періоді (1894-1918) за короткий термін (5 років) було створено 14 кафедр, запроваджено вивчення нових предметів (біологічної хімії, гістології з ембріологією, патологічної анатомії, гігієни, шкірно-венеричних хвороб, педіатрії, нервових та психічних хвороб, оториноларингології, стоматології). Змін зазнала і сама організація процесу навчання. Філософський факультет з підготовчого відділу переріс у самостійний, рівноправний 3 іншими факультетами. Тому навчання власне на медичному факультеті тривало 5 років і здійснювалося згідно з новою програмою, як у Варшавському університеті [7].

Вища фармацевтична освіта почала розвиватися у Львові лише після підписання імператором Австро-Угорщини Францом-Йосифом I указу про створення у 1854-1855 н. р. фармацевтичного відділення при філософському факультеті Львівського університету. Заняття відбувались за дворічною програмою і проводили їх професори філософського факультету та медико-хірургічного відділення. Фармацевти вважались нетрадиційними слухачами, й, окрім обов'язкових предметів, їм рекомендувалося відвідувати й інші заняття природничого напрямку. В 1889 р. відбулась реформа фармацевтичної освіти в Австрії. Згідно з цією реформою, асистентська практика скасовувалась, а навчання в університеті розпочиналось після іспиту. Було введено вимогу закінчення шести класів гімназії як неодмінну умову прийняття учня до аптеки [4]. 
Короткий аналіз стану медичної освіти на Волині, у Галичині, на Закарпатті та Буковині, проведений сучасними дослідниками, дозволяє стверджувати, що у цих регіонах західноукраїнських земель збільшилася кількість навчальних закладів; урізноманітнилися їх типи (акушерські школи, фельдшерські школи, медичний факультет і медичний колегіум); підвищився рівень вимог до вступників (зараховували лише письменних); поєднувалася теоретична і практична підготовка, а в Галичині, зокрема у Львові, більшу частину наукових медичних курсів здійснювали відомі на той час вчені-лікарі, професори, що природно сприяло підвищенню освітнього рівня випускників.

До 1918 р. у підготовці майбутніх медиків перевагу віддавали словесним методам навчання (лекціям, розповідям, поясненням), рідше застосовували наочні (ілюстрування, демонстрування). Серед практичних методів навчання набули поширення практичні роботи і вправи; лабораторні роботи в цей час тільки почали запроваджуватися. Переважальною формою організації навчання були лекції. Вони займали приблизно половину від усієї кількості навчальних занять (а з історії та філософії медицини були єдиною формою). Тоді ж почалося впровадження циклів практичних занять за тематикою спецкурсів. Практичні й лабораторні заняття проводилися у відповідно обладнаних кабінетах i лабораторіях (майстернях), що мали достатню кількість необхідних засобів навчання (таблиць, копій наукових праць, трупів, лабораторних тварин), приладів (мікроскопів, електрокардіографів, фото- і рентгенапаратів, міографів). У цей же період зазнали диференціації та спеціалізації клінічні дисципліни, що спричинило виділення з курсу внутрішніх хвороб самостійних предметів: пульмонології, кардіології, гастроентерології, нефрології, ендокринології та ін. [7].

Процес навчання здійснювався на основі принципів наочності, науковості, систематичності, послідовності, зв’язку навчання з життям, грунтовності й міцності, активності. Засоби навчання збагачено та урізноманітнено підручниками, написаними німецькою і польською мовами. Про посилення уваги в процесі підготовки майбутніх лікарів до формування практичних умінь та навичок свідчить введення чергувань студентів у клініках. Для поточного контролю успішності використовували “ригороз” (державний іспит) та короткий іспит, для заключного - ригороз у присутності комісії. На- вчання було платним. Важливим нововведенням стало відкриття на факультеті регулярних доповнювальних курсів для лікарів [7].

Як зазначають дослідники, до початку XX ст. на західноукраїнських землях не було рідномовних закладів медичної освіти. Однак українські лікарі Галичини для вирішення проблем охорони здоров’я українців та розвитку національної медичної науки пішли шляхом створення лікарських товариств. Найважливішими факторами, що спричинили процес виникнення та становлення професійних товариств українських лікарів, були: необхідність забезпечення автохтонного населення західноукраїнських земель висококваліфікованими національними медичними кадрами; організація лікувально-профілактичної, санітарно-гігієнічної та просвітницької роботи серед населення; забезпечення можливостей професійного зростання лікарів. Так, 2 грудня 1867 р. львівські медики створили Товариство галицьких лікарів, де спочатку було 47 осіб, відтак до них приєдналися лікарі 3 повітових галицьких сіл. Товариство галицьких лікарів, попри основні станові завдання, у своїй діяльності включало елементи наукової праці. Невдовзі виникають повітові товариства, до прикладу, у Дрогобичі - 1908 р. За прикладом лікарів станові товариства з метою захисту своїх професійних прав організували аптекарі, зубні техніки, бальнеологи. У 1892 р. було засновано математично-прородописно-лікарську секцію (далі МПЛС) Наукового товариства ім. Т. Шевченка (НТШ), котра в 1898 р. переросла у Лікарську комісію (ЛК). 1900 р. за ініціативи львівських лікарів було створене товариство “Поліклініка Львівська”, метою якого стала спільна науково-медична праця. Ця інституція мала доброчинний характер: своїм завданням львівські лікарі вважали надання безкоштовної лікарської допомоги малозабезпеченим хворим, постачання їм ліків зі знижкою. Поліклініка Львівська у своїй структурі мала амбулаторію та лабораторію. Наукова діяльність відбувалася шляхом організації науково-практичних конференцій та видань медичних часописів. Таким чином, забезпечувалося тісне поєднання теоретичної та практичної медицини $[1,7] .1903$ р. створено товариство “Народна лічниця” (НЛ), а згодом (1910) на його основі Українське лікарське товариство (УЛТ). Це товариство, очолене Є. Озаркевичем, здійснювало підготовку молодих медичних кадрів і поширювало серед населення елементарні медичні знання; ство- 
рило спеціальну комісію, що розробляла українську медичну термінологію; співпрацювало з подібними організаціями за кордоном; відстоювало права українського населення Австро-Угорщини в столиці і на місцях; здійснювало гігієнічне виховання і культурно-просвітницьку роботу серед населення (з 1912 р. видавало часопис “Здоровлє”, редактором якого і автором більшості статей у журналі був Є. І. Озаркевич) $[6,10,11]$.

Почесним головою цього товариства було обрано великого українського вченого, професора медичної хімії в Празі І. Я. Горбачевського.

Життєвий шлях І. Я. Горбачевського (1854-1942) починається з с. Зарубинці Збаразького району на Тернопільщині. Упродовж 35 років він очолював кафедру біохімії Карлового університету в Празі. Після Першої світової війни він був ректором українського університету в цьому ж місті; з 1925 р. академік АН УРСР. Горбачевський перший синтезував із сечовини й гліцину сечову кислоту, встановив джерела і шляхи утворення її в організмі, відкрив фермент ксантиноксидазу; створив велику школу чеських біохіміків. Змушений працювати на чужині, він ніколи не забував свого рідного народу, вивчав питання про харчування населення Поділля, розробляв українську хімічну термінологію, написав перший підручник з біохімії українською мовою [4, 5].

Іван Горбачевський паралельно втілював у життя національну ідею: він активний член товариств “Громада” та “Січ”, з 1899 р. - дійсний член НТШ [12]. Великий внесок він зробив в організацію і становлення Українського лікарського товариства, створеного на основі Наукового товариства ім Т. Г. Шевченка, його обрано першим почесним головою. Учений активно співпрацював з українськими науковцями та лікарями-практиками у Львові, 4 жовтня 1911 р. його обрано головою математично-природописно-лікарської секції, яку очолював до 1918 р., основною заслугою цієї праці стала реалізація проекту створення української наукової термінології в ділянках медицини та хімії $[1,4,5]$.

Непересічною подією в житті Івана Горбачевського та, врешті, і розвитку не тільки вітчизняної, а й європейської медицини стало створення першого у світі спеціалізованого Міністерства народного здоров'я 1917 р. як окремого структурного підрозділу уряду Австро-Угорщини. Як зазначають дослідники його діяльності, саме за цією схемою, враховуючи український досвід, аналогічні міністерства були організовані в Англії, Франції, Другій Речі Посполитій, інших країнах світу. Власне, автором ідеї та її практичним реалізатором став Іван Горбачевський, який розробив проект Міністерства охорони здоров'я, став його першим міністром (з 20 липня 1918 р. - до кінця жовтня 1918 р.) [1, 5]. Досвід практичної діяльності у такого роду структурах у нього були: член Краєвої санітарної ради у Празі, член Найвищої санітарної ради у Відні (1906). Закономірно, що саме Іван Горбачевський докладав чимало зусиль до створення Українського вільного університету 1921 р., який очолив у 1923 р. [1].

3 початком Першої світової війни діяльність товариства і випуск журналу припинилися. Цікавою і змістовною була також просвітницька і профілактична діяльність товариства “Медична Громада” (МГ), створеного в 1910 р. українськими студентами медичного факультету університету імені Франца I [7].

Яскраву сторінку у розвиток новітньої української медицини вписав іï фундатор - лікар Євген Озаркевич. Народився в с. Белелуя Снятинського повіту 8 травня 1861 р. у сім’ї священика. Батько Іван Озаркевич - священик, громадський діяч, інтелектуал, володів декількома європейськими мовами, укомплектував велику домашню бібліотеку, брав участь у діяльності “Руської Бесіди”, понад 20 років був послом (депутатом) крайового сейму, а згодом - Віденського парламенту; мати Теофілія - з роду Окуневських. Оселя Озаркевичів була осередком української культури, і серед друзів та рідних ії називали “Руськими Атенами”. Це не випадково, адже родина Озаркевичів - класичний приклад справжньої української еліти: брат Євгена Лонгин Озаркевич став юристом, працював адвокатом у Городку біля Львова (радянський режим 1939 р. його, літнього і хворого, разом з дочкою та зятем позбавив права жити та працювати на рідній землі: їх арештовано та вивезено до Росії, подальша доля не відома); брат Володимир Озаркевич, священик у Белелуї, одружився з Ольгою Рошкевич (нареченою Івана Франка); сестра Наталія вийшла заміж за Теофіла Кобринського, стала письменницею і громадським діячем; сестра Єроніма поріднилася з родичами Соломії Крушельницької, відома як колекціонер народних мистецьких виробів, 1925 р. переїхала до радянської України, 1937 р., вочевидь, була репресована, подальша доля не відома $[1,3,6]$. 
Євген Озаркевич відзначався глибокою ерудицією, винятковою працездатністю, кипучою енергією, організаторськими здібностями, невтомним бажанням працювати для України, був людиною високої культури, добре знав класичні та іноземні мови, зарубіжну медичну літературу, українську культуру. Євген Озаркевич упродовж усього 55-ти років (8 травня 1861 р. - 21 вересня 1916 р.) зробив для розвитку української науки, вітчизняної медицини та національного поступу українців, соціальної та медичної опіки найменш захищених верств населення стільки, скільки б вистачило на життя не одному поколінню фахівців. Він автор перших україномовних наукових медичних праць, дійсний член НТШ, очільник лікарської комісії НТШ, засновник і редактор “Лікарського збірника” - першого україномовного науково-медичного видання, перший укладач наукової української медичної термінології, автор багатьох науково-практичних та громадсько-політичних публікацій, засновник і редактор першого українського санітарно-гігієнічного журналу “Здоровлє”, ініціатор створення і директор (до кінця свого життя) першої української амбулатоpiї “Народна лічниця”, перший голова УЛТ у Львові, представник українських лікарів на низці міжнародних наукових конгресів, активний діяч “Просвіти”, старший санітарний радник та член Найвищої ради здоров’я у Відні $[1,6]$. У передмові до місячника “Здоровлє” Є. Озаркевич писав: “Народ, що вже є народом справді культурним, мусить мати накопичені у своїм письменстві всі віти людського знання”. Він наголошував на необхідності громадської підтримки розвитку гігієнічних знань у народу та медичних наук рідною мовою, довгий час очолював львівську “Просвіту”. Є. Озаркевич - приклад лікаря-науковця і просвітянина, будівничого української культури і науки. Діяльність та ім'я цього патріота замовчували в добу тоталітаризму [4].

Євген Озаркевич опублікував українською мовою перші в новітній історії наукові медичні праці з лабораторного дослідження при хворобах печінки та діагностики малярії, був першим доцентом, який започаткував викладання медичних дисциплін українською мовою, першим з вітчизняних лікарів офіційно ставив питання про необхідність відкриття у Львові українського медичного факультету з використанням “Народної лічниці” як його клінічної бази; першим почав публікувати українською мовою реферати та рецензії статей з нових європейських журналів (заснував перше українське ре- феративне видання), видав низку цінних матеріалів 3 різних галузей гігієни, що дозволяють вважати його першим українським гігієністом, опублікував перші українські праці з курортології, сприяв відкриттю в Підлютому першого українського санаторію для хворих на туберкульоз, започаткувавши таким чином українську курортологію; своєю книгою “Пошесні недуги” заклав в українській медицині основи вчення про інфекційні хвороби [3]. Низка цих починів Євгена Озаркевича набагато випереджувала його епоху.

Незважаючи на значну недосконалість системи здоров’я в Австро-Угорській імперії, саме вона, на думку багатьох дослідників, дала поштовх до зародження і подальшого розвитку української медицини та формування медичної інтелігенції. Цьому сприяло і виникнення низки українських лікарських інституцій, станових (професійних), наукових товариств [1].

Висновки. Отже, розвиток медичної освіти на західноукраїнських землях у другій половині XVIII 60-х роках XX ст. був складним і суперечливим. На цей процес впливало багато взаємопов’язаних чинників: особливості історичного, політичного та соціально-економічного розвитку, досвід європейських країн, реорганізація закладів медичної освіти та охорони здоров’я відповідно до внутрішньої політики, відкриття державних та приватних закладів освіти, діяльність різноманітних лікарських товариств. Визначальними критеріями процесу розвитку медичної освіти можна назвати: поступове зростання мережі закладів медичної освіти, збільшення числа кафедр, збільшення кількості студентів і викладачів у них, розширення змісту навчання, зміна рівня професійної підготовки медиків; підвищився рівень вимог до вступників (зараховували лише письменних); поєднувалася теоретична і практична підготовка, а в Галичині, зокрема у Львові, більшу частину наукових медичних курсів здійснювали відомі на той час вчені-лікарі, професори, що природно сприяло підвищенню освітнього рівня випускників. За свідченням багатьох дослідників, саме Західній Україні належить пріоритет у формуванні поглядів на сестринську справу як особливий вид медичної діяльності, який вимагає відповідної теоретичної та практичної підготовки.

До подальших досліджень можна віднести порівняльний аналіз становлення і розвитку медичної освіти на східно- і західноукраїнських землях у другій половині XVIII - XIX ст. 


\section{Список літератури}

1. Білавич I. В. Становлення і розвиток громадської системи охорони здоров'я в Галичині наприкінці XIX на початку XX ст. [Електронний ресурс] / I. В. Білавич. Режим доступу : http://www.sworld.com.ua/simpoz4/65.pdf.

2. Верхратський С. А. Історія медицини : навч. посіб. / С. А. Верхратський, П. Ю. Заблудовський. - 4-те вид., випр. і доповн. - К. : Вища школа, 1991. - 431 с. ; [Електронний ресурс] Режим доступу : http://www. bookish.link/istoriya-meditsiny/medichna-dopomogazahidnoukrajinskih-83793.html.

3. Ганіткевич Я. Історія української медицини в датах та іменах. НТШ та ін. / Я. Ганіткевич. - Львів, 2004. 365 c.

4. Голяченко О. Історія медицини: посіб. / О. Голяченко, Я. Ганіткевич. - 2-ге вид., доповн. - Тернопіль : ТДМУ, 2016. - 326 с.

5. Гонський Я. Іван Горбачевський в спогадах і листуванні / Я. Гонський. - Тернопіль : Укрмедкнига, 2004. $184 \mathrm{c}$.

6. Євген Озаркевич // Енциклопедія українознавства. Словникова частина / гол. ред. В. Кубійович. - Перевидання в Україні. - Львів : НТШ, 1996. - Т. 5. - С. 1831.

7. Клос Л. Є. Розвиток медичної освіти на західноукраїнських землях (друга половина XVIII - 30-ті роки

\section{References}

1. Bilavych, I.V. (2015). Stanovlennia i rozvytok hromadskoi systemy okhorony zdorovia $v$ Halychyni naprykintsi XIX - na pochatku XX st. [Formation and development of public health care system in Halychyna in the late XIX - early XX century]. Retrieved from: http: // www.sworld.com.ua/simpoz4/65.pdf [in Ukrainian].

2. Verkhratskyi, S.A., \& Zabludovskyi, P.Yu. (1991). Istoriia medytsyny: navchalnyi posibnyk [History of medicine: textbook]. Kyiv: Vyshcha shkola. Retrieved from: http://www.bookish.link/istoriya-meditsiny/medichnadopomoga-zahidnoukrajinskih-83793.html [in Ukrainian].

3. Hanitkevych, Ya. (2004). Istoriia ukrainskoi medytsyny $v$ datakh ta imenakh. [The history of the Ukrainian medicine in dates and names]. Lviv [in Ukrainian].

4. Holiachenko, O., \& Hanitkevych, Ya. (2016). Istoriia medytsyny: posibnyk [History of medicine: manual]. Ternopil [in Ukrainian].

5. Honskyi, Ya. Ivan Horbachevskyi v spohadakh i lystuvanni [Ivan Horbachevskyi in memoirs and correspondence]. Ternopil: Ukrmedknyha [in Ukrainian].

6. Kubiiovych, V. (Ed.). (1996). Yevhen Ozarkevych [Yevhen Ozarkevych]. Entsyklopediia ukrainoznavstva. Slovnykova chastyna - Encyclopedia of Ukraine. The vocabulary section, 5. Lviv: NTSh [in Ukrainian].
XX ст.) : афтореф. дис. на здобуття наук. ступ. канд. пед. наук / Л. Є. Клос. - К., 2002. - 20 с.

8. Круківська I. М. Медична освіта на Західноукраїнських землях: ретроспектива становлення (XIX - поч. XX ст.) / I. М. Круківська // Вісн. Житомир. держ. ун-ту ім. І. Франка. - 2005. - № 25. - С. 194-196.

9. Кушик М. Л. Організація медичної освіти в Україні в другій половині XIX - початку XX ст. [Електронний ресурс] / М. Л. Кушик. - Режим доступу : http://www. rusnauka.com/26_SSN_2008/Pedagogica/34933.doc.htm.

10. Медицина // Енциклопедія українознавства. Словникова частина / гол. ред. В. Кубійович. - Перевидання в Україні. - Львів : НТШ, 1996. - Т. 5. - С. 1506-1507.

11. Медична освіта // Енциклопедія українознавства. Словникова частина / гол. ред. В. Кубійович. Перевидання в Україні. - Львів : НТШ, 1996. - Т. 5. C. $1509-1510$.

12. Наукові праці, документи і матеріали професора Івана Горбачевського : до 150-річчя від дня його народження / [упор. і автор передм. І. Д. Головацький]. Львів, 2005. - 292 с.

13. Шапиро И. Я. Из истории медицинского образования в западных областях Украины и на Буковине / И. Я. Шапиро. - Львов : Изд-во Львов. ун-та, 1957. - 61 с.

7. Klos, L.Ye. (2002). Rozvytok medychnoi osvity na zakhidnoukrainskykh zemliakh (druha polovyna XVIII 30-ti roky XX st.) [The development of medical education in the Western Ukrainian regions (the second part of the 18th - the thirties of the 20th century)]. Extended abstract of Candidate's thesis. Kyiv [in Ukrainian].

8. Krukivska, I.M. (2015). Medychna osvita na zakhidnoukrainskykh zemliakh : retrospektyva stanovlennia (XX - poch. XX st.) [Medical education in Western Ukrainian lands: Retrospectives of formation (XIX- early XX cent.)]. Visnyk Zhytomyrskoho derzhavnoho universytetu im. I. Franka: Journal of Ivan Franko Zhytomyr State University, 25, 194-196 [in Ukrainian].

9. Kushyk, M.L. Orhanizatsiia medychnoi osvity v Ukraini v druhii polovyni XIX - poch. XX st. [The development of higher medical education in the late XIX early XX century]. Pedahohicheskiie nauki. 2. Problemy podhotovki spetsyalistov - Pedagogical sciences. 2. The issues of specialists' training. Retrieved from: http://www. rusnauka.com/26_SSN_2008/Pedagogica/34933.doc.htm [in Ukrainian].

10. Kubiiovych, V. (Ed.). (1996). Medytsyna [Medicine]. Entsyklopediia ukrainoznavstva. Slovnykova chastyna Encyclopedia of Ukraine. The vocabulary section, 5, 15061507. Lviv: NTSh [in Ukrainian]. 


\section{3 ІСТОРІЇ МЕДИЧНИХ НАВЧАЛЬНИХ ЗАКЛАДІВ}

11. Kubiiovych, V. (Ed.). (1996). Medychna osvita [Medical education]. Entsyklopediia ukrainoznavstva. Slovnykova chastyna - Encyclopedia of Ukraine. The vocabulary section, 5, 1509-1510. Lviv: NTSh [in Ukrainian].

12. Holovatskyi, I.D. (Ed.). (2005). Naukovi pratsi, dokumenty i materialy profesora Ivana Horbachevskoho: Do 150-richchia vid dnia ioho narodzhennia [Professor Ivan
Horbachevsky's scientific works, documents and materials: dedicated to the 150th anniversary of his birth]. Lviv [in Ukrainian].

13. Shapiro, I.Ya. (1957). Iz istorii meditsinskoho obrazovaniya $v$ zapadnykh oblastiakh Ukrainy i na Bukovine [From the history of medical education in the western regions of Ukraine and in Bukovina]. Lvov: Izd-vo Lvov. un-ta [in Russian]. 